\title{
Control of Diastereoselectivity by Solvent Effects in the Addition of Grignard Reagents to Enantiopure $t$ - Butylsulfinimine: Syntheses of the Stereoisomers of the Hydroxyl Derivatives of Sibutramine
}

\author{
Bruce Z. Lu*a , Chris Senanayake ${ }^{\star b}$, Nansheng Li, Zhengxu Han, Roger P. Bakale, \\ and Stephen A. Wald \\ Chemical Process Research and Development, Sepracor Inc., 84 Waterford Drive, Marlborough, MA \\ 01752 \\ zlu@rdg.boehringer-ingelheim.com
}

\section{Supporting Information}

General: All reactions were carried out in oven-dried glassware sealed with rubber septa under an inert atmosphere of dry argon. All commercial materials were used without further purification. Chemical yields refer to pure isolated substances. Purification of products was accomplished by flash column chromatography. ${ }^{1} \mathrm{H}$ and ${ }^{13} \mathrm{C}$ NMR were recorded using a Varian Inova 300 spectrometer. Chemical shifts are reported in ppm. The following abbreviations were used to designate chemical shift multiplicities: $\mathrm{s}=$ singlet, $\mathrm{d}=$ doublet, $\mathrm{t}=$ triplet, $\mathrm{q}=$ quartet, $\mathrm{h}=$ heptet, $\mathrm{m}=$ multiplet, $\mathrm{br}=$ broad . $\mathrm{LC}$ MS was recorded on Agilent MSD spectrometer with VL API-ES positive scan. High resolution mass spectra were obtained on VG Fison AutoSpec mass spectrometer S/N M297 at $70 \mathrm{eV}$.

(R)-N-(1-(4-Chlorophenyl)cyclobutanemethylene)-t-butanesulfinamide (1): To a solution of 1-(4-chlorophenyl)cyclobutanecarbaldehyde (2) (10.0 g, $51.0 \mathrm{mmol})$, were added $(R)$ - $t$-butanesulfinamide $(5.0 \mathrm{~g}, 41.0 \mathrm{mmol})$ in THF $(60 \mathrm{~mL})$ and Ti(OEt $)_{4}(46.8 \mathrm{~g}$, $205 \mathrm{mmol})$. The reaction mixture was stirred at room temperature for $3 \mathrm{~h}$ and poured into ice-water. The solid was filtered off, and the filtration was extracted with ethyl acetate. The extracts were dried over magnesium sulfate and the solvents were removed on rotovapor. The residue was purified by chromatography on silica gel eluting with heptane/ethyl acetate $=9 / 1(\mathrm{v} / \mathrm{v})$ to give $11.2 \mathrm{~g}$ of $\mathbf{1}$ in $92 \%$ yield. ${ }^{1} \mathrm{H} \mathrm{NMR}\left(\mathrm{CDCl}_{3} / \mathrm{TMS}\right)$ : $\delta 8.03(\mathrm{~s}, 1 \mathrm{H}), 7.30(\mathrm{~d}, J=8.4 \mathrm{~Hz}, 2 \mathrm{H}), 7.10(\mathrm{~d}, J=8.4 \mathrm{~Hz}, 2 \mathrm{H}), 2.85-2.60(\mathrm{~m}, 2 \mathrm{H}), 2.60-$ $2.40(\mathrm{~m}, 2 \mathrm{H}), 2.15-1.85(\mathrm{~m}, 2 \mathrm{H}), 1.19(\mathrm{~s}, 9 \mathrm{H}) .{ }^{13} \mathrm{C} \mathrm{NMR}\left(\mathrm{CDCl}_{3}\right): \delta 170.6,142.5,132.5$, 128.7, 127.5, 57.0, 51.8, 31.1, 30.8, 22.3, 15.9. Anal. Calcd for $\mathrm{C}_{15} \mathrm{H}_{20} \mathrm{ClNOS}$ : C, 60.49; H, 6.77; N, 4.70. Found: C, 60.61; H, 6.80; N, 4.64. 
(R)-3-(Tetrahydropyran-2-yloxyl)-2-methylpropyllithium [(R)-3]: To the suspension of lithium $(0.3 \mathrm{~g}, 43.2 \mathrm{mmol})$ in ether $(5 \mathrm{~mL})$ at $0{ }^{\circ} \mathrm{C},(S)$-2-(3-Bromo-2-methylpropoxy) tetrahydropyran $(4.22 \mathrm{~g}, 17.8 \mathrm{mmol})$ in ether $(7 \mathrm{~mL})$ was slowly added. After the reaction was initiated, the reaction mixture was stirred at -10 to $-5{ }^{\circ} \mathrm{C}$ while the rest of the bromide was added within 1.5 hour. After the addition of the bromide was complete, the reaction mixture was stirred at -10 to $-5{ }^{\circ} \mathrm{C}$ for 1 hour. The concentration of this lithium reagent was measured as $0.77 \mathrm{M}$ by titration and the yield is $51 \%$.

General procedure for addition of organolithium $(R)-3$ to butanesulfinamide (1). The preparation of anti $(2 R, 4 R)-\mathbf{4}$ (Table 1 , entry 6) was described as the general procedure for all the experiments as shown in Table 1 . To the solution of $(R)-t$ butanesulfinamide (1) $(0.595 \mathrm{~g}, 2.0 \mathrm{mmol})$ in THF $(10 \mathrm{~mL})$ at $-78{ }^{\circ} \mathrm{C}$, was added $\mathrm{Al}(\mathrm{Oct})_{3}$ $(5 \mathrm{~mL}, 25 \mathrm{wt} \%$ in hexane, $2.4 \mathrm{mmol})$. After the mixture was stirred at $-78{ }^{\circ} \mathrm{C}$ for $5 \mathrm{~min}$., organolithium $(R)-3(5.2 \mathrm{~mL}, 0.77 \mathrm{M}$ in ether, $4 \mathrm{mmol})$ was added. The reaction mixture was stirred at $-78{ }^{\circ} \mathrm{C}$ for 2 hours and then quenched with methanol $(5 \mathrm{~mL})$. The reaction mixture was allowed to warm to room temperature, diluted with TBME, washed with brine and dried over anhydrous $\mathrm{MgSO}_{4}$. A sample $(1 \mathrm{~mL})$ was token and treated with $2 \mathrm{~N}$ $\mathrm{HCl}$ in methanol to cleave the sulfinyl auxiliary and the resulting sample was analyzed by HPLC to measure the diastereoselectivity (dr 99:1). After removal of the solvents, the crude product was purified by chromatography on silica gel (eluting with 5\% ethyl acetate in heptane) to give $0.75 \mathrm{~g}$ of anti-4 in $82 \%$ yield. ${ }^{1} \mathrm{H}$ NMR $\left(\mathrm{CDCl}_{3} / \mathrm{TMS}\right): \delta 7.27$ $(\mathrm{m}, 4 \mathrm{H}), 4.46(\mathrm{~m}, 1 \mathrm{H}), 3.80-3.60(\mathrm{~m}, 1 \mathrm{H}) 3.44(\mathrm{~m}, 3 \mathrm{H}), 3.08(\mathrm{~m}, 1 \mathrm{H}), 2.87(\mathrm{~d}, J=10.4 \mathrm{~Hz}$, $1 \mathrm{H}), 2.71(\mathrm{~m}, 1 \mathrm{H}), 2.41(\mathrm{~m}, 2 \mathrm{H}), 2.14(\mathrm{~m}, 1 \mathrm{H}), 2.0-1.3(\mathrm{~m}, 10 \mathrm{H}), 1.16(\mathrm{~s}, 9 \mathrm{H}), 1.0-0.8(\mathrm{~m}$, $4 \mathrm{H}) .{ }^{13} \mathrm{C}$ NMR $\left(\mathrm{CDCl}_{3}\right): \delta 142.1,131.9,130.0,127.7,98.7,98.5,73.1,73.0,62.9,62.0$, $61.8,56.6,50.7,35.5,35.4,34.6,32.2,30.5,29.5,25.4,22.8,19.4,19.2,16.0,15.2$.

General procedure for addition of Grignard reagent $(R)$-or $(S)$-5 to $(R)-t$ butanesulfinamide (1).

See reference 8 for preparation of the racemic Grignard reagent 5 in diethyl ether. The following improved procedure uses THF as solvent for better solubility.

Preparation of $(\boldsymbol{R})-5$ : To the solution of $(R)$-3-bromo-2-methylpropanol (15.3 g, 100 $\mathrm{mmol})$ in THF $(30 \mathrm{~mL})$ at $-35^{\circ} \mathrm{C}$ was added $i-\mathrm{PrMgCl}(51 \mathrm{~mL}, 2.0 \mathrm{M}$ in THF, $102 \mathrm{mmol})$ via syringe. After the addition was complete, the reaction mixture was continued to stir at $0{ }^{\circ} \mathrm{C}$ for 1 hour. The resulting magnesium salt solution was then slowly added into a suspension of magnesium turnings $(4.0 \mathrm{~g}, 165 \mathrm{mmol})$ in THF $(20 \mathrm{~mL})$. After the reaction was initiated, the reaction mixture was maintained with an inner temperature at between $40-50{ }^{\circ} \mathrm{C}$ during the addition of the THF solution of the magenesium salt. After the addition was complete, the reaction mixture was stirred at ambient temperature for $2 \mathrm{~h}$. This homogeneous solution was used for the addition reaction under various conditions and the results are shown in Table 2 (entries 1-4).

Preparation of $(2 S, 4 S)$-6 (Table 2, entry 1$)$ :

To a solution of $(R)$-t $t$-butanesulfinamide $1(2.98 \mathrm{~g}, 10.0 \mathrm{mmol})$ in dichloromethane (100 $\mathrm{mL}$ ) at $-48{ }^{\circ} \mathrm{C}$, was added the Grignard reagent $(\boldsymbol{R})-5(53 \mathrm{~mL}, 0.38 \mathrm{M}$ in ether, 20.0 $\mathrm{mmol}$ ). The reaction mixture was allowed to warm to room temperature and stirred for 24 hours. The reaction mixture was quenched by addition of water $(10 \mathrm{~mL})$, and extracted 
with TBME. The extracts were dried over $\mathrm{MgSO}_{4}$. After removal of the solvents, a sample of the crude product was taken and treated with $2 \mathrm{~N} \mathrm{HCl}$ in methanol to cleave the sulfinyl auxiliary and the resulting sample was analyzed by HPLC to measure the diastereoselectivity (dr 97:3). The major diastereomer $6(2.75 \mathrm{~g}, 74 \%)$ and the minor diastereomer $7(0.10 \mathrm{~g}, 2.7 \%)$ were isolated in $77 \%$ combined yield by chromatography on silica gel, eluting with ethyl acetate/heptane (6:4).

6: ${ }^{1} \mathrm{H}$ NMR ( $\left.\mathrm{CDCl}_{3} / \mathrm{TMS}\right): \delta 7.27(\mathrm{~d}, \mathrm{~J}=8.4 \mathrm{~Hz}, 2 \mathrm{H}), 7.07(\mathrm{~d}, \mathrm{~J}=8.4 \mathrm{~Hz}, 2 \mathrm{H}), 3.60-3.38$ (m, 2H), 3.15-2.90 (m, 3H), 2.45-1.70 (m, 7H), 1.40-0.95 (m, 2H), $1.25(\mathrm{~s}, 9 \mathrm{H}), 0.92(\mathrm{~d}, \mathrm{~J}$ $=6.8 \mathrm{~Hz}, 3 \mathrm{H}) .{ }^{13} \mathrm{C} \mathrm{NMR}\left(\mathrm{CDCl}_{3}\right): \delta 143.9,132.3,129.1,128.1,68.7,64.8,57.2,51.2$, 37.1, 33.3, 32.5, 32.2, 23.4, 17.7, 15.2. Anal. Calcd for $\mathrm{C}_{19} \mathrm{H}_{30} \mathrm{ClNO}_{2} \mathrm{~S}: \mathrm{C}, 61.35 ; \mathrm{H}, 8.13$; N, 3.77. Found: C, 61.25; H, 8.42; N, 3.28.

\section{Preparation of $(2 S, 4 R)-7$}

The following experiment (Table 2, entry 3 ) is described as the representative procedure: To a solution of $(R)$ - $t$-butanesulfinamide $1(5.95 \mathrm{~g}, 20.0 \mathrm{mmol})$ in THF $(60 \mathrm{~mL})$ at $-78{ }^{\circ} \mathrm{C}$, was added the Grignard reagent $(\boldsymbol{R})-5(58 \mathrm{~mL}, 0.7 \mathrm{M}$ in THF, $40.6 \mathrm{mmol})$. The reaction mixture was allowed to warm to room temperature and completed in 2 hours. The reaction mixture was quenched by the addition of water $(20 \mathrm{~mL})$, and extracted with TBME. The extracts were dried over $\mathrm{MgSO}_{4}$. After removal of the solvents, a sample of the crude product was taken and treated with $2 \mathrm{~N} \mathrm{HCl}$ in methanol to cleave the sulfinyl auxiliary and the resulting sample was analyzed by HPLC to measure the diastereoselectivity ( $\mathrm{dr} 40: 60)$. The major diastereomer 7 (4.24 g, 57\%) and the minor diastereomer 6 (2.82 g, 38\%) were isolated in 95\% combined yield by chromatography on silica gel, eluting with a mixture of ethyl acetate/heptane $=6 / 4(\mathrm{v} / \mathrm{v})$.

7: ${ }^{1} \mathrm{H}$ NMR $\left(\mathrm{CDCl}_{3} / \mathrm{TMS}\right): \delta$ 7.30-7.20 (m, 4H), 3.65-3.45 (m, 3H), $2.94(\mathrm{~d}, J=10.2 \mathrm{~Hz}$, $1 \mathrm{H}), 2.75-2.60(\mathrm{~m}, 1 \mathrm{H}), 2.45-2.30(\mathrm{~m}, 2 \mathrm{H}), 2.30-1.50(\mathrm{~m}, 6 \mathrm{H}), 1.18(\mathrm{~s}, 9 \mathrm{H}), 0.88(\mathrm{~d}, J=$ $6.8 \mathrm{~Hz}, 3 \mathrm{H}), 0.58(\mathrm{~m}, 1 \mathrm{H}) .{ }^{13} \mathrm{C} \mathrm{NMR}\left(\mathrm{CDCl}_{3}\right): \delta 142.1,132.0,130.1,127.9,66.2,63.5$, 56.7, 50.7, 35.6, 34.5, 32.2, 31.6, 22.9, 18.5, 15.2. Anal. Calcd for $\mathrm{C}_{19} \mathrm{H}_{30} \mathrm{ClNO}_{2} \mathrm{~S}: \mathrm{C}$, 61.35; H, 8.13; N, 3.77. Found: C, 61.32; H, 8.26; N, 3.40.

Preparation of $(\mathbf{2} R, \mathbf{4 S})-\mathbf{8}$ (Table 2 , entry 5$)$ :

To a solution of $(R)$-t-butanesulfinamide $1(4.0 \mathrm{~g}, 13.4 \mathrm{mmol})$ in dichloromethane (110 $\mathrm{mL})$ at $0{ }^{\circ} \mathrm{C}$, Grignard reagent $(S)-5(54 \mathrm{~mL}, 0.5 \mathrm{M}$ in ether, $27.0 \mathrm{mmol})$ was added. The reaction was allowed to warm to room temperature and completed in 10 hours. A sample was analyzed by HPLC to measure the diastereoselectivity ( $\mathrm{dr} 91: 9)$. The major diastereomer 8 (3.82 g, 76.5\%) and the minor diastereomer $9(0.40 \mathrm{~g}, 8 \%)$ were isolated in $84.5 \%$ combined yield by chromatography on silica gel, eluting with ethyl acetate/heptane (6/4).

8: ${ }^{1} \mathrm{H}$ NMR $\left(\mathrm{CDCl}_{3} / \mathrm{TMS}\right): \delta 7.27(\mathrm{~d}, J=8.2 \mathrm{~Hz}, 2 \mathrm{H}), 7.11(\mathrm{~d}, J=8.2 \mathrm{~Hz}, 2 \mathrm{H}), 4.04(\mathrm{~m}$, $1 \mathrm{H}), 3.70-3.40(\mathrm{~m}, 2 \mathrm{H}), 3.23$ (brs, 1H), $2.72(\mathrm{~d}, J=8.2 \mathrm{~Hz}, 1 \mathrm{H}), 2.35(\mathrm{~m}, 2 \mathrm{H}), 2.16(\mathrm{~m}$, 2H), $2.04(\mathrm{~m}, 2 \mathrm{H}), 1.92-1.70(\mathrm{~m}, 1 \mathrm{H}), 1.54(\mathrm{~m}, 1 \mathrm{H}), 1.28(\mathrm{~s}, 9 \mathrm{H}), 0.95-0.65(\mathrm{~m}, 4 \mathrm{H}) .{ }^{13} \mathrm{C}$ NMR $\left(\mathrm{CDCl}_{3}\right): \delta 143.6,131.8,129.0,127.6,68.4,61.5,56.5,51.0,37.8,32.2,31.8,30.7$, 23.1, 18.8, 15.0. Anal. Calcd for $\mathrm{C}_{19} \mathrm{H}_{30} \mathrm{ClNO}_{2} \mathrm{~S}$ : C, 61.35; H, 8.13; N, 3.77. Found: C, $61.41 ; \mathrm{H}, 8.17 ; \mathrm{N}, 3.60$. The absolute configuration of $\mathbf{8}$ was assigned by $\mathrm{x}$-ray of the crystals. 
Preparation of $(\mathbf{2} \boldsymbol{R}, \mathbf{4 R})-\mathbf{9}$ (Table 2, entry 7$)$ :

To a solution of $(R)-t$-butanesulfinamide $1(4.0 \mathrm{~g}, 13.4 \mathrm{mmol})$ in THF $(90 \mathrm{~mL})$ at $0{ }^{\circ} \mathrm{C}$, Grignard reagent $(S)-5(35 \mathrm{~mL}, 0.6 \mathrm{M}$ in THF, $21.0 \mathrm{mmol})$ was added. The reaction was allowed to warm to room temperature and completed in 2 hours. A sample was analyzed by HPLC to measure the diastereoselectivity (dr 85:15). The major diastereomer 9 (3.74 $\mathrm{g}, 74.9 \%)$ and the minor diastereomer $8(0.67 \mathrm{~g}, 13.4)$ were isolated in $88 \%$ combined yield by chromatography on silica gel, eluting with ethyl acetate/heptane (6/4).

9: ${ }^{1} \mathrm{H}$ NMR (CDCl 3 /TMS): $\delta 7.29$ (m, 4H), 3.55-3.30 (m, 3H), $2.94(\mathrm{~d}, J=10.2 \mathrm{~Hz}, 1 \mathrm{H})$, 2.75-2.65 (m, 1H), 2.47-2.35 (m, 2H), 2.20-2.10 (m, 1H), 2.00-1.80 (m, 4H), $1.17(\mathrm{~s}, 9 \mathrm{H})$, $0.94(\mathrm{~d}, J=6.7 \mathrm{~Hz}, 3 \mathrm{H}), 1.25-0.85(\mathrm{~m}, 2 \mathrm{H}) .{ }^{13} \mathrm{C}$ NMR $\left(\mathrm{CDCl}_{3}\right): \delta 142.1,132.0,130.1$, 127.9, 68.5, 63.0, 56.7, 50.7, 34.9, 34.6, 32.3, 31.9, 22.8, 15.6, 15.2. Anal. Calcd for $\mathrm{C}_{19} \mathrm{H}_{30} \mathrm{ClNO}_{2} \mathrm{~S}: \mathrm{C}, 61.35 ; \mathrm{H}, 8.13 ; \mathrm{N}, 3.77$. Found: C, 61.17; H, 8.36; N, 3.44.

(2S, 4R)-4-Amino-4-[1-(4-chlorophenyl)cyclobutyl]-2-methyl-butan-1-ol [(2S, 4R)- 4]: To the solution of $7(3.50 \mathrm{~g}, 9.4 \mathrm{mmol})$ in methanol $(50 \mathrm{~mL})$ at $\mathrm{rt}$, was added the solution of $\mathrm{HCl}$ in $i-\mathrm{PrOH}(10 \mathrm{~mL}, 5-6 \mathrm{~N})$. The reaction mixture was stirred at room temperature overnight. After the solvent was removed under vacuum, the residue was purified by chromatography on silica gel, eluting with heptane/ethyl acetate/triethylamine (1/9/0.2) to give $(2 S, 4 R)-4\left(2.52 \mathrm{~g}, 100 \%\right.$ yield). ${ }^{1} \mathrm{H}$ NMR $\left(\mathrm{CDCl}_{3} / \mathrm{TMS}\right): \delta 7.31(\mathrm{~d}, \mathrm{~J}=8.4 \mathrm{~Hz}, 2 \mathrm{H})$, $7.07(\mathrm{~d}, \mathrm{~J}=8.4 \mathrm{~Hz}, 2 \mathrm{H}), 3.49(\mathrm{~m}, 2 \mathrm{H}), 3.14(\mathrm{~d}, \mathrm{~J}=10.9 \mathrm{~Hz}, 1 \mathrm{H}), 2.64$ (brs, $3 \mathrm{H}), 2.50-$ $2.10(\mathrm{~m}, 4 \mathrm{H}), 2.10-1.80(\mathrm{~m}, 3 \mathrm{H}), 1.64-1.57(\mathrm{~m}, 1 \mathrm{H}), 1.01(\mathrm{~d}, \mathrm{~J}=7.1 \mathrm{~Hz}, 3 \mathrm{H}), 0.78(\mathrm{~m}$, $1 \mathrm{H}) .{ }^{13} \mathrm{H}$ NMR $\left(\mathrm{CDCl}_{3}\right): \delta 143.6,131.8,128.6,127.8,66.7,53.4,51.2,36.6,32.9,31.7$, 31.4, 16.1, 15.0.

(2R, 4S)-4-Amino-4-[1-(4-chlorophenyl)cyclobutyl]-2-methyl-butan-1-ol [(2R, 4S)- 4]: To the solution of $8(3.36 \mathrm{~g}, 9.0 \mathrm{mmol})$ in methanol $(50 \mathrm{~mL})$ at room temperature, the solution of $\mathrm{HCl}$ in i-PrOH $(10 \mathrm{~mL}, 5-6 \mathrm{~N})$ was added. The reaction mixture was stirred at room temperature overnight. After the solvent was removed under vacuum, the residue was purified by chromatography on silica gel, eluting with heptane/ethyl acetate/triethylamine (1/9/0.2) to give $(2 R, 4 S)-4\left(2.35 \mathrm{~g}, 97 \%\right.$ yield). The ${ }^{1} \mathrm{H}$ and ${ }^{13} \mathrm{C}$ NMR are identical to the enantiomer $(2 S, 4 R)-4$.

(2S, 4S)-4-Amino-4-[1-(4-chlorophenyl)cyclobutyl]-2-methyl-butan-1-ol [(2S, 4S)-4]: To the solution of $6(3.21 \mathrm{~g}, 8.6 \mathrm{mmol})$ in methanol $(50 \mathrm{~mL})$ at room temperature, the solution of $\mathrm{HCl}$ in $\mathrm{i}-\mathrm{PrOH}(10 \mathrm{~mL}, 5-6 \mathrm{~N})$ was added. The reaction mixture was stirred at room temperature overnight. After the solvent was removed under vacuum, the residue was purified by chromatography on silica gel, eluting with heptane/ethyl acetate/triethylamine $(1 / 9 / 0.2)$ to give $(2 S, 4 S)-\mathbf{4}(2.30 \mathrm{~g}, 100 \%$ yield $) .{ }^{1} \mathrm{H}$ NMR $\left(\mathrm{CDCl}_{3} / \mathrm{TMS}\right): \delta 7.31(\mathrm{~d}, \mathrm{~J}=8.3 \mathrm{~Hz}, 2 \mathrm{H}), 7.06(\mathrm{~d}, \mathrm{~J}=8.4 \mathrm{~Hz}, 2 \mathrm{H}), 3.49(\mathrm{dd}, \mathrm{J}=3.2,11.5$ $\mathrm{Hz}, 1 \mathrm{H}), 3.30-2.80(\mathrm{~m}, 5 \mathrm{H}), 2.50-2.10(\mathrm{~m}, 4 \mathrm{H}), 2.10-1.60(\mathrm{~m}, 3 \mathrm{H}), 1.64-1.57(\mathrm{~m}, 1 \mathrm{H})$, $0.85(\mathrm{~d}, \mathrm{~J}=6.8 \mathrm{~Hz}, 3 \mathrm{H}), 0.46-0.35(\mathrm{~m}, 1 \mathrm{H}) .{ }^{13} \mathrm{H} \mathrm{NMR}\left(\mathrm{CDCl}_{3}\right): \delta 143.7,132.2,128.9$, $128.1,69.2,58.7,51.7,40.1,37.9,32.0,31.8,19.5,15.1$.

(2R, 4R)-4-Amino-4-[1-(4-chlorophenyl)cyclobutyl]-2-methyl-butan-1-ol [(2R, 4R)-4]: To the solution of $9(3.08 \mathrm{~g}, 8.3 \mathrm{mmol})$ in methanol $(50 \mathrm{~mL})$ at room temperature, the solution of $\mathrm{HCl}$ in i-PrOH $(10 \mathrm{~mL}, 5-6 \mathrm{~N})$ was added. The reaction mixture was stirred at 
room temperature overnight. After the solvent was removed under vacuum, the residue was purified by chromatography on silica gel, eluting with heptane/ethyl acetate/triethylamine (1/9/0.2) to give $(2 R, 4 R)-4(2.22 \mathrm{~g}, 99 \%$ yield $)$. The ${ }^{1} \mathrm{H}$ and ${ }^{13} \mathrm{C}$ NMR are identical to amino alcohol $(2 S, 4 S)-4$. 